\title{
Bacterial Sanitary Survey of Drinking Water Quality in Some Areas in Giza Governorate
}

\author{
REHAB H. BAHY, Ph.D.*; NOURAN H. ASSAR, Ph.D.* and GHADA S. MOHAMED, Ph.D.** \\ Researcher of Microbiology and Immunology at Microbiology Department*, National Organization for Drug Control and \\ Research (NODCAR), Giza, Egypt and Researcher of Microbiology at Microbiology Department**, National Organization for \\ Drug Control and Research (NODCAR), Giza, Egypt
}

\begin{abstract}
Background: Drinking water should be clear and free from unpleasant tastes and odors and from injurious chemicals and microorganisms. Water-borne diseases have been predicted to cause more than two million deaths and four billion cases of diarrhea each year.
\end{abstract}

Aim of Study: This Bacteriological study was conducted on water samples from three areas in Giza Governorate, namely Kerdasa, Kafr El-Gebel and Dahshur, from December 2016 till November 2017, to screen Bacterial Sanitary of Drinking Water Quality in these areas in Giza Governorate.

Material and Methods: Water samples $(n=846)$ were collected from tap water, hand pump water, plant water and source water at the four seasons. Fecal and total coliform were detected using the standard membrane filtration technique.

Results: The results obtained were compared with WHO guidelines. Among the total coliforms, E.coli, Salmonella spp., Shigella spp. and Klebsiella spp. were reported.

Conclusions: Concern should be rasied about the quality of the drinking water in area of study should be taken.

Key Words: Fecal and total coliform - E. coli-Salmonella spp. - Shigella spp. - Klebsiella spp.

\section{Introduction}

WATER is essential to human life, and availability of safe drinking water is very important. To achieve this, reliance has to be placed on regular bacteriological analyses to assess potability and to detect the best course of action for guarding the population from waterborne diseases. Drinking water should be clear, cool and free from unpleasant tastes and odors and from injurious chemicals and microorganisms. Water-borne diseases have been predicted to cause more than two million deaths and four billion cases of diarrhea each year [1]. Infectious

Correspondence to: Dr. Rehab H. Bahy, Researcher of Microbiology and Immunology, Microbiology Department, National Organization for Drug Control and Research (NODCAR), Giza, Egypt diarrhea is bound to the greatest burden of this morbidity and mortality, and children less than five years of age are the most severely injured populations [2].

In Egypt, the Nile River is the main source of drinking water; every effort should be made to attain drinking water quality as high as applicable, otherwise people life are extremely subjected to difficult effects. Applicable selection and protection of water sources to be used for supplying water analysis systems are of prime importance in the equipping of safe drinking water [3]

The desired healthful qualities are required, absence from harmful microorganisms is not easy to achieve. It is not impossible, but it requires constant vigilance and much more testing. The problem has become more acute because water sources are exposed to contamination by human and animal wastes which most probably includes a variety of bacteria, viruses and other microbial pathogens. Water containing only a very few pathogens in each liter may by adequately polluted to cause the increase of infectious diseases such as cholera, typhoid, dysentery, hepatitis,... etc. Water purification to be used for drinking is therefore necessary and must be commanded by constant testing. To be safe for human utilization, water must be turbidity, odour and taste free [4]. The presence of faecal coliform or thermotolerant coliform organisms per $100 \mathrm{ml}$ is an indication of some degree of faecal contamination [5]. The presence of E.coli is particularly taken as particularly indicative of pollution of water [6]. Pathogens are a serious concern for managers of water resources, because extreme amounts of faecal bacteria in water have been known to signify the risk of pathogen-induced illnesses in humans [7]. The principal water related diseases caused by bacteria are chol- 
era, salmonellosis and shigellosis. Most of bacterial pathogens found in wastewater can be an important cause of the infections of gastrointestinal tract of warm-blooded animals. They mostly belong to the following genera: Vibrio, Salmonella, Shigella, and E.coli [8]

Failure to provide acceptable protection and persuasive treatment will expose the community to the danger of outbreaks of intestinal and other infectious diseases. Easy diffusible assays are in need for risk assessment of water supply systems [9], for example by monitoring of raw water quality, assessment of treatment effectiveness, monitoring of finished water quality as well as recreational waters.

For selecting a bacteriological analytical technique there are two techniques are commonly used to detect the presence of coliforms in water. The first is called the "multiple fermentation tube" or "most probable number" technique. In this method measured portions of a water sample are placed in test-tubes containing a culture medium. The tubes are then incubated for a standard time at a standard temperature. In the second technique, a measured volume of sample is passed through a fine filter that retains bacteria. The filter is then placed on culture medium and incubated. This is called the "membrane filter" technique [10]

Accordingly, the goal of the present investigation was to estimate the microbiological water quality of some areas in Giza Governorate, tap water, hand pump water, plant water and source water applying Membrane Filter (MF) technique.

\section{Material and Methods}

Study area:

Giza Governorate is one of the governorates of Egypt; (Image 1). It is the third largest city in Egypt. It is located on the west bank of the Nile, southwest of central Cairo. The city of Giza is the capital of the Giza Governorate, and is located near the northeast border of this governorate in coordinates. Major tourist destinations include the Pyramids and Great Sphinx at Giza.

We chose three areas to study water bacterial sanitary in, (Image 2), which were:

- Kerdasa, is a village in Giza Governorate nearby Giza Plateau, it is famed for its hand-made textile crafts, woven carpets, and wall hangings in native traditional patterns. Area 1.

- Kafr El-Gebel, a part of the Giza necropolis situated southeast of the Pyramids, by the Man- souria Canal, entrance to Sound and light show at Pyramids area, Area 2.

-Dahshur is a royal necropolis located in the desert on the west bank of the Nile approximately 40 $\mathrm{km}$ south of Cairo. It is known chiefly for several pyramids, two of which are among the oldest, largest and best preserved in Egypt, Area 3.

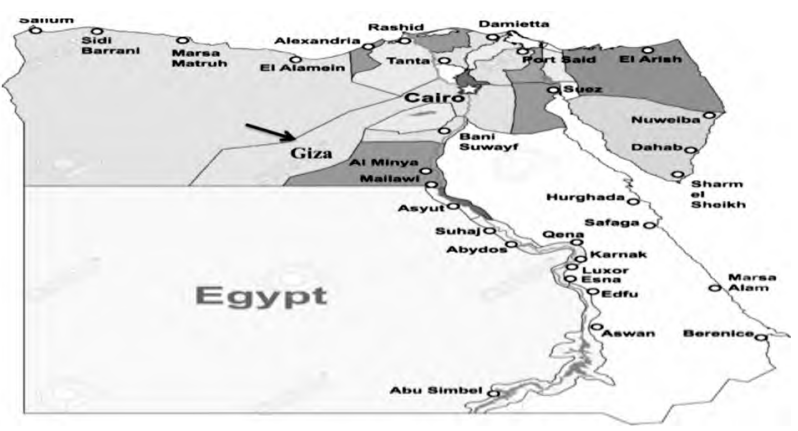

Image (1): Egypt Map with pointer on Giza governorate.

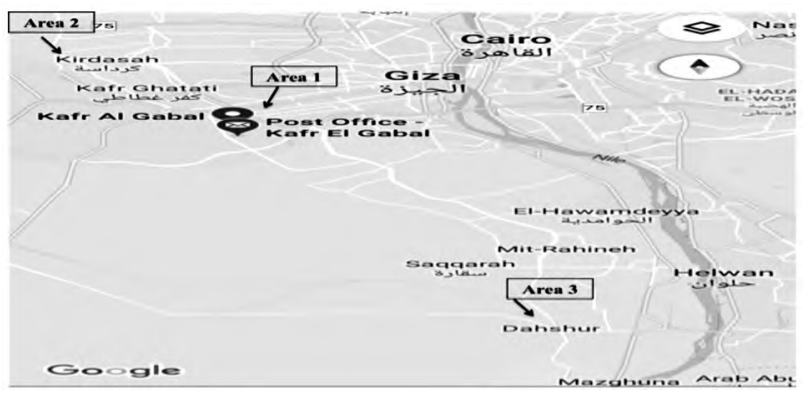

Image (2): Areas of study.

\section{Sample collection:}

Water samples were collected from each area for one complete year, from December 2016 till November 2017, from three different points and three water sources per area, sampling frequency was twice per month, triplicate for every point of collection through 12 month $(n=864)$. One of our study objectives is to assess the quality of the water supplied and of that at the point of use, so that samples were taken: Tap water (P1) (allow the tap to run with cold water for three to five minutes before taking the sample, sterilize the end of the tap with the flame from a lighter or by using disinfectant if there are any plastic components, cut the flow of water to a gentle stream to avoid splashing or overfilling the sample bottle, remove the cap from the sample bottle and take the required sample volume [11]), hand pump water (P2), plant (P3) and Source (P4).

Samples should be securely labeled with a unique sample number at the sampling site and transported to the analyzing laboratory as soon as possible after collection [12]. The samples were 
transported to the laboratory in an ice box. Water samples were collected into sterile bottles in 100 $\mathrm{ml}$ amounts and processed within 2 hours of collection [13]

Bacteriological analysis: Fecal and total coliform counts were performed using the standard Membrane Filtration (MF) technique. $100 \mathrm{ml}$ water sample was filtered using membrane filters, sterile white $0.45 \mu \mathrm{m}$ pore size, $47 \mathrm{~mm}$ diameter filter membrane as described by APHA [14]. Throughout the monitoring period 864 water samples were analyzed by MF technique. The prevalence of various water borne pathogens and indicators organisms examined using specialized media and biochemical tests for identification of bacteria. Enteric bacteria isolated on respective selective or differential media were identified on the basis of their colonial, morphological and Biochemical properties, Table (1), following Bergey's Manual of Determinative Bacteriology [15] .

Statistical methods were employed to ensure that the selected sampling locations and timing represent both indicator behavior and study area. Statistical presentation and analysis of the present study were conducted, using chi-square test by Graphpad prism software for windows. Differences were considered significant when $p$-value was $<0.05$.

Table (1): Biochemical tests and selective or differential media selective or differential media selective or differential media.

Biochemical testing/selective media or differential media

Type of Bacteria to be identified

- Kovacs' reagent (Paradimethyl amino benzaldehyde + Isoamyl alcohol + Sulphuric acid).

- Mac-Conkey agar (is the earliest selective and differential medium for cultivation of coliform organisms)

- E.coli.

[16]

- Citrase utilization test (Simmon's citrate medium + Bromo thymol indicator).

- Urease test (urea is digested by urease enzyme resulted in release of ammonia).

- Oxidase reaction (Tetra methyl parapholene diamine dihydro chloride).

- Triple sugar iron test (TSI) (for differentiation of various members of Enterobacteriaceae).

In addition to:

- M-EC Test Agar is used for testing E.coli in water samples using membrane filter technique [16,17]

- Salmonella Shigella (S.S) agar is moderately selective and differential medium for the isolation, cultivation and differentiation of Salmonella spp. and some strains of Shigella spp. [18]

- Fluid Thioglycolate Media (FTM) enrichment broth for anaerobes, aerobes, microaerophilic, and fastidious organisms [19].

- XLD (used for the isolation and differentiation of enteric pathogens) [20]

- Eosin Methylene Blue Agar (EMB) is recommended for the isolation and differentiation of gram negative enteric bacteria from clinical and nonclinical specimens [21]

\section{Results}

\section{Sample collection:}

Throughout the monitoring period 864 water samples were analyzed by the membrane filtration technique, Table (2) illustrates number of samples collected from each season per area and point of use.

Table (2): Number of samples collected from each season per area and point of use.

\begin{tabular}{lllll}
\hline & \multicolumn{4}{c}{ Season } \\
\cline { 2 - 5 } & Winter & Spring & Summer & Autumn \\
\hline Number of samples & 216 & 216 & 216 & 216 \\
Areas: & Area 1 & Area 2 & Area 3 & \\
Number of samples & 288 & 288 & 288 & \\
Point of use: & P1 & P2 & P3 & P4 \\
Number of samples & 72 & 72 & 72 & 72 \\
\hline
\end{tabular}

Bacteriological analysis:

In the present Bacteriological analysis, total coliform count and E.coli count, were analyzed biochemically and using selective and differential media and results shown in (Table 3 ).

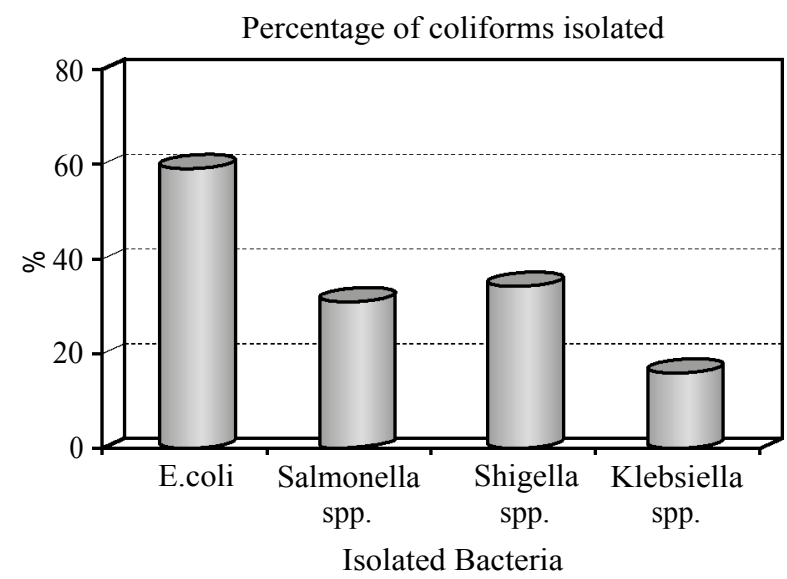

Fig. (1): Percent of coliforms isolated. 
Table (3): Colonial, morphological and biochemical properties of water borne pathogens and indicators organisms.

\begin{tabular}{|c|c|c|}
\hline $\begin{array}{l}\text { Biochemical testing/ } \\
\text { selective media or } \\
\text { differential media }\end{array}$ & Results & Type of Bacteria \\
\hline - Kovacs' reagent. & - Appearance of pink colored ring. & - Indicates the presence of E.coli. \\
\hline - Mac-Conkey agar. & $\begin{array}{l}\text { - Lactose fermenting strains grows as red or pink and was } \\
\text { surrounded by a zone of acid precipitated bile. }\end{array}$ & - Indicates the presence of E.coli and K. pneumoniae. \\
\hline - Citrase utilization test. & - Appearance of green colour in the medium. & - Indicates the presence of E.coli. \\
\hline - Urease test. & - Appearance of yellow colour shows negative. & $\begin{array}{l}\text { - Indicates the presence of E.coli, Shigella spp. or Salmonella } \\
\text { spp. }\end{array}$ \\
\hline & - Appearance of pink colour positive. & - Indicates the presence K.pneumoniae. \\
\hline - Oxidase Test. & - No purple colour. & - Indicates the presence of E.coli. \\
\hline - TSI. & $\begin{array}{l}\text { - Change in media color to yellow or black and gas pro- } \\
\text { duction. }\end{array}$ & $\begin{array}{l}\text { - Indicates the presence of K.pneumonia, E.coli and Sal- } \\
\text { monella spp. }\end{array}$ \\
\hline \multicolumn{3}{|l|}{ In addition to: } \\
\hline - M-EC Test Agar. & - Yellow colonies. & - Indicates the presence of E.coli. \\
\hline - S.S agar. & $\begin{array}{l}\text { - Colorless colonies with black centers. } \\
\text { - Colorless colonies. }\end{array}$ & $\begin{array}{l}\text { - Indicates the presence of Salmonella spp. } \\
\text { - Indicates the presence of Shigella spp. }\end{array}$ \\
\hline & - Pink colonies. & - Indicates the presence of E.coli. \\
\hline \multirow{3}{*}{ • FTM. } & - Mucoid, pale, opaque cream to pink colonies & - Indicates the presence of Enterobacter and Klebsiella spp. \\
\hline & - Growth seen at the top of the test tube. & - Indicates the presence of obligate aerobe \\
\hline & $\begin{array}{l}\text { - Hrowth seen at the bottom of the test tube. } \\
\text { - Heavy growth seen at the top of the tube and growth } \\
\text { throughout the tube. }\end{array}$ & $\begin{array}{l}- \text { Indicates the presence of obligate anaerobe. } \\
\text { - Indicates the presence of facultative anaerobe. }\end{array}$ \\
\hline - XLD. & $\begin{array}{l}\text { - Yellow to yellow-red colonies. } \\
\text { - Red colonies with black centers. } \\
\text { - Red colonies. }\end{array}$ & $\begin{array}{l}\text { - Indicates the presence of E.coli. } \\
\text { - Indicates the presence of Salmonella spp. } \\
\text { - Indicates the presence of Shigella spp. }\end{array}$ \\
\hline - EMB agar. & $\begin{array}{l}\text { - Purple colonies with black centre and green metallic } \\
\text { sheen. }\end{array}$ & - Indicates the presence of E.coli. \\
\hline
\end{tabular}

\section{Findings of bacteriological analyses:}

In this study, 864 isolates of coliform bacteria obtained were primary identified as E.coli (59.5\%), Salmonella spp. (3 1.6\%), Shigella spp. (34.7\%), Klebsiella spp. (16.7\%), data shown in Fig. (1).

Data in (Table 4) shown that E.coli were present in tap water (P1) by $18.9 \%$, hand pump water (P2) by $28.2 \%$, plant (P3) by $30.7 \%$ and source (P4) by 24.5\%. While Salmonella spp. tap water (P1) by $19.4 \%$, hand pumps water (P2) by $19.4 \%$, plant (P3) by $36.9 \%$ and source (P4) by $24.2 \%$, for Shigella spp. were present in tap water (P1) by $28.7 \%$, hand pumps water (P2) by $25.33 \%$, plant (P3) by $17 \%$ and source (P4) by $29 \%$ and Klebsiella spp. were present in tap water (P1) by $21 \%$, hand pumps water (P2) by $26.8 \%$, plant (P3) by $23.9 \%$ and source (P4) by $28.3 \%$.

Table (4): Percentage of bacterial isolates in point of use.

\begin{tabular}{lllll}
\hline \multirow{2}{*}{ Bacterial isolate } & \multicolumn{4}{c}{ Point of use } \\
\cline { 2 - 5 } & $\mathrm{P} 1$ & $\mathrm{P} 2$ & $\mathrm{P} 3$ & $\mathrm{P} 4$ \\
\hline E.coli & $18.9 \%$ & $28.2 \%$ & $73.8 \%$ & $24.5 \%$ \\
Salmonella spp. & $19.4 \%$ & $19.4 \%$ & $36.9 \%$ & $24.2 \%$ \\
Shigella spp. & $28.7 \%$ & $25.33 \%$ & $17 \%$ & $39 \%$ \\
Klebsiella spp. & $21 \%$ & $26.8 \%$ & $23.9 \%$ & $28.3 \%$ \\
\hline
\end{tabular}

As regards the distribution of positive samples examined for E.coli, Salmonella spp., Shigella spp., and Klebsiella spp. in relation to season, area, and point of use, it was noticed that positive sam- ples were present in all seasons in each area per every point of use except in spring for area 1 (Kerdasa) and 3 (Dahshur) at point of use P1 (tap water), as shown in (Table 5) and Fig. (2).

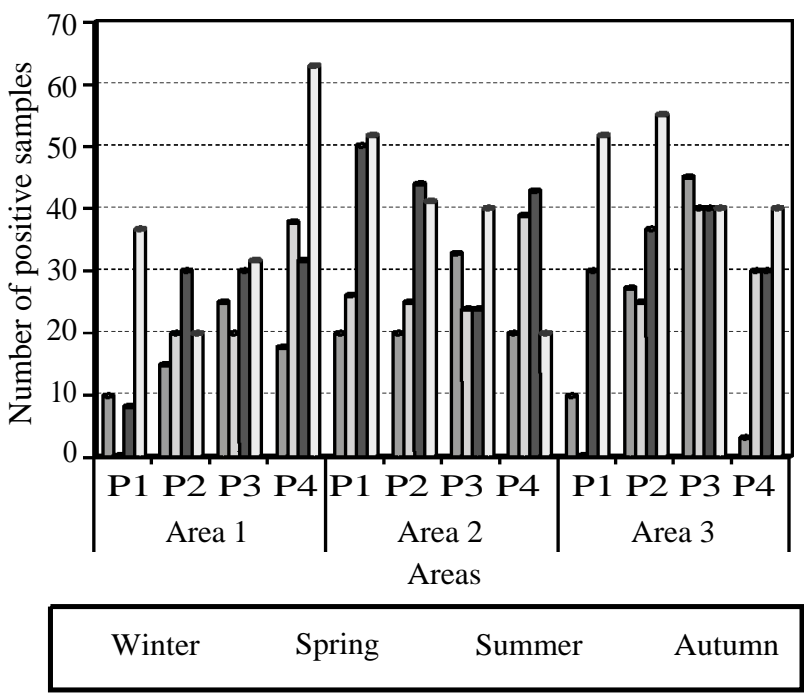

Fig. (2): Number of positive samples per seasons in each area per every point of use.

The most contaminated Season was autumn followed by summer, Fig. (3), while Area 2 (Kafr El-Gebel) and Area 3 (Dahshur) were highly contaminated, Fig. (4), and for sampling points P4 and P3 followed by P1 and P2 especially in summer and autumn were also contaminated, Fig. (5). The difference was statistically significant $(p=0.0001$, 0.0012 and 0.0001 , respectively), Table (6). 
Table (5): E. coli, Salmonella spp., Shigella spp. and Klebsiella spp. positive isolates from water samples per seasons in each area per every point of use.

\begin{tabular}{|c|c|c|c|c|c|c|c|c|c|c|c|c|}
\hline \multirow[b]{2}{*}{ Seasons } & \multicolumn{4}{|c|}{ Area $1(n=288)$} & \multicolumn{4}{|c|}{ Area $2(n=288)$} & \multicolumn{4}{|c|}{ Area $3(n=288)$} \\
\hline & $\begin{array}{c}\text { P1 } \\
(n=72)\end{array}$ & $\begin{array}{c}\text { P2 } \\
(n=72)\end{array}$ & $\begin{array}{c}\text { P3 } \\
(n=72)\end{array}$ & $\begin{array}{c}\mathrm{P} 4 \\
(\mathrm{n}=72)\end{array}$ & $\begin{array}{c}P 1 \\
(n=72)\end{array}$ & $\begin{array}{c}\text { P2 } \\
(n=72)\end{array}$ & $\begin{array}{c}\text { P3 } \\
(n=72)\end{array}$ & $\begin{array}{c}\mathrm{P} 4 \\
(\mathrm{n}=72)\end{array}$ & $\begin{array}{c}P 1 \\
(n=72)\end{array}$ & $\begin{array}{c}\text { P2 } \\
(n=72)\end{array}$ & $\begin{array}{c}\text { P3 } \\
(n=72)\end{array}$ & $\begin{array}{c}\mathrm{P} 4 \\
(\mathrm{n}=72)\end{array}$ \\
\hline \multicolumn{13}{|l|}{ Winter $(n=216)$ : } \\
\hline E.coli & $+\mathrm{ve}$ & +ve & $+\mathrm{ve}$ & +ve & +ve & +ve & +ve & +ve & +ve & +ve & +ve & +ve \\
\hline Salmonella spp. & $+\mathrm{ve}$ & $+\mathrm{ve}$ & $+\mathrm{ve}$ & $+v e$ & $+\mathrm{ve}$ & $+\mathrm{ve}$ & $+v e$ & $+\mathrm{ve}$ & $+\mathrm{ve}$ & $+\mathrm{ve}$ & $+\mathrm{ve}$ & $+\mathrm{ve}$ \\
\hline Shigella spp. & $+\mathrm{ve}$ & $+\mathrm{ve}$ & $+\mathrm{ve}$ & $+\mathrm{ve}$ & $+\mathrm{ve}$ & $+\mathrm{ve}$ & $+\mathrm{ve}$ & $+\mathrm{ve}$ & $+\mathrm{ve}$ & $+v e$ & $+\mathrm{ve}$ & $+\mathrm{ve}$ \\
\hline Klebsiella spp. & $+\mathrm{ve}$ & $+\mathrm{ve}$ & $+\mathrm{ve}$ & $+v e$ & $+\mathrm{ve}$ & $+\mathrm{ve}$ & $+\mathrm{ve}$ & $+v e$ & $+v e$ & $+\mathrm{ve}$ & $+\mathrm{ve}$ & $+v e$ \\
\hline \multicolumn{13}{|l|}{ Spring $(n=216)$ : } \\
\hline E.coli & $-\mathrm{ve}$ & $+\mathrm{ve}$ & $+v e$ & $+\mathrm{ve}$ & $+v e$ & $+v e$ & $+v e$ & $+v e$ & $-\mathrm{ve}$ & $+v e$ & $+v e$ & $+v e$ \\
\hline Salmonella spp. & $-\mathrm{ve}$ & $+v e$ & $+v e$ & $+\mathrm{ve}$ & +ve & $+\mathrm{ve}$ & $+v e$ & $+v e$ & $-\mathrm{ve}$ & $-\mathrm{ve}$ & $+\mathrm{ve}$ & +ve \\
\hline Shigella spp. & $-\mathrm{ve}$ & $+\mathrm{ve}$ & $-\mathrm{ve}$ & $+\mathrm{ve}$ & $+\mathrm{ve}$ & $+\mathrm{ve}$ & $-\mathrm{ve}$ & $+\mathrm{ve}$ & $-\mathrm{ve}$ & $+\mathrm{ve}$ & $-\mathrm{ve}$ & $+\mathrm{ve}$ \\
\hline Klebsiella spp. & $-\mathrm{ve}$ & $+\mathrm{ve}$ & $+\mathrm{ve}$ & $+\mathrm{ve}$ & - ve & $-\mathrm{ve}$ & - ve & $+\mathrm{ve}$ & $-\mathrm{ve}$ & $+\mathrm{ve}$ & $+\mathrm{ve}$ & $+\mathrm{ve}$ \\
\hline \multicolumn{13}{|l|}{ Summer $(n=216)$ : } \\
\hline E.coli & $+v e$ & $+v e$ & $+v e$ & $+v e$ & $+v e$ & $+\mathrm{ve}$ & $+v e$ & $+v e$ & $+\mathrm{ve}$ & $+v e$ & $+\mathrm{ve}$ & $+v e$ \\
\hline Salmonella spp. & $-\mathrm{ve}$ & $+\mathrm{ve}$ & $+\mathrm{ve}$ & $+\mathrm{ve}$ & $+\mathrm{ve}$ & $+v e$ & + ve & $+\mathrm{ve}$ & $-\mathrm{ve}$ & $-\mathrm{ve}$ & $-\mathrm{ve}$ & $-\mathrm{ve}$ \\
\hline Shigella spp. & $+\mathrm{ve}$ & $+v e$ & $+\mathrm{ve}$ & $+v e$ & $+v e$ & $+\mathrm{ve}$ & $+v e$ & $+v e$ & $+\mathrm{ve}$ & $+v e$ & $+\mathrm{ve}$ & $+v e$ \\
\hline Klebsiella spp. & + ve & + ve & $+v e$ & $+\mathrm{ve}$ & $+v e$ & +ve & $+v e$ & $+v e$ & $-\mathrm{ve}$ & $-\mathrm{ve}$ & - ve & $-\mathrm{ve}$ \\
\hline \multicolumn{13}{|l|}{ Autumn $(n=216)$ : } \\
\hline E.coli & $+\mathrm{ve}$ & $+\mathrm{ve}$ & $+\mathrm{ve}$ & $+\mathrm{ve}$ & $+\mathrm{ve}$ & +ve & $+\mathrm{ve}$ & $+\mathrm{ve}$ & $+v e$ & $+\mathrm{ve}$ & $+\mathrm{ve}$ & $+\mathrm{ve}$ \\
\hline Salmonella spp. & $+\mathrm{ve}$ & $+v e$ & $+v e$ & $+v e$ & $+v e$ & $-\mathrm{ve}$ & $+v e$ & $-\mathrm{ve}$ & $+\mathrm{ve}$ & $+\mathrm{ve}$ & $+\mathrm{ve}$ & $+v e$ \\
\hline Shigella spp. & +ve & $-\mathrm{ve}$ & - ve & $+\mathrm{ve}$ & $+\mathrm{ve}$ & +ve & $+v e$ & - ve & $+\mathrm{ve}$ & $+\mathrm{ve}$ & $+\mathrm{ve}$ & $+\mathrm{ve}$ \\
\hline Klebsiella spp. & - ve & - ve & $+v e$ & $+v e$ & $+\mathrm{ve}$ & +ve & $+v e$ & - ve & $+\mathrm{ve}$ & $+v e$ & $+v e$ & - ve \\
\hline
\end{tabular}

*+ve indicates the presence of bacterial growth, whereas -ve denotes the absence of bacterial growth.

Table (6): Number of samples contaminated by E.coli, Salmonella spp., Shigella spp., and Klebsiella spp. in relation seasons, areas and points of use.

\begin{tabular}{|c|c|c|c|c|c|}
\hline Variables & E.coli & $\begin{array}{l}\text { Salmonella } \\
\text { spp. }\end{array}$ & $\begin{array}{l}\text { Shigella } \\
\text { spp. }\end{array}$ & $\begin{array}{l}\text { Klebsiella } \\
\text { spp. }\end{array}$ & $\begin{array}{l}\chi^{2} \\
p\end{array}$ \\
\hline \multicolumn{6}{|c|}{ Season $(216$} \\
\hline Winter & 100 & 45 & 36 & 15 & 37.42 \\
\hline Spring & 101 & 65 & 41 & 32 & $>0.0001 *$ \\
\hline Summer & 150 & 60 & 107 & 31 & \\
\hline Autumn & 163 & 103 & 116 & 66 & \\
\hline \multicolumn{6}{|l|}{ Area $(288$} \\
\hline Area 1 & 157 & 105 & 38 & 73 & 21.99 \\
\hline Area 2 & 190 & 105 & 50 & 110 & $0.0012 *$ \\
\hline Area 3 & 167 & 63 & 50 & 117 & \\
\hline \multicolumn{6}{|c|}{ Point of use (72 } \\
\hline \multicolumn{6}{|c|}{ sample/point): } \\
\hline $\mathrm{P} 1$ & 97 & 53 & 86 & 29 & 4015 \\
\hline $\mathrm{P} 2$ & 145 & 53 & 76 & 37 & $<0.0001 *$ \\
\hline P3 & 158 & 101 & 51 & 33 & \\
\hline P4 & 126 & 66 & 87 & 39 & \\
\hline
\end{tabular}

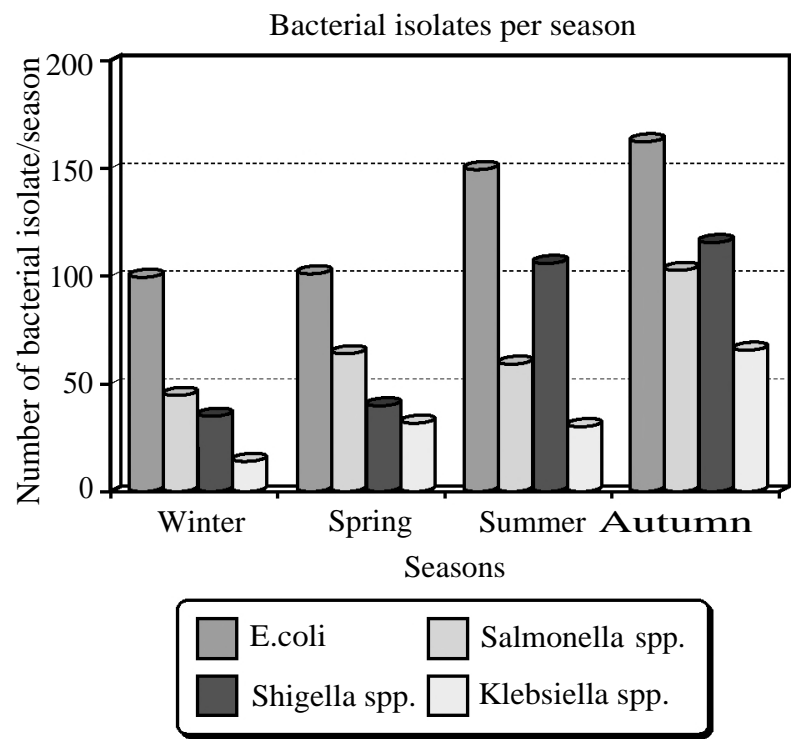

*: Significant $(p<0.05)$

Fig. (3): Bacterial isolates per season. 


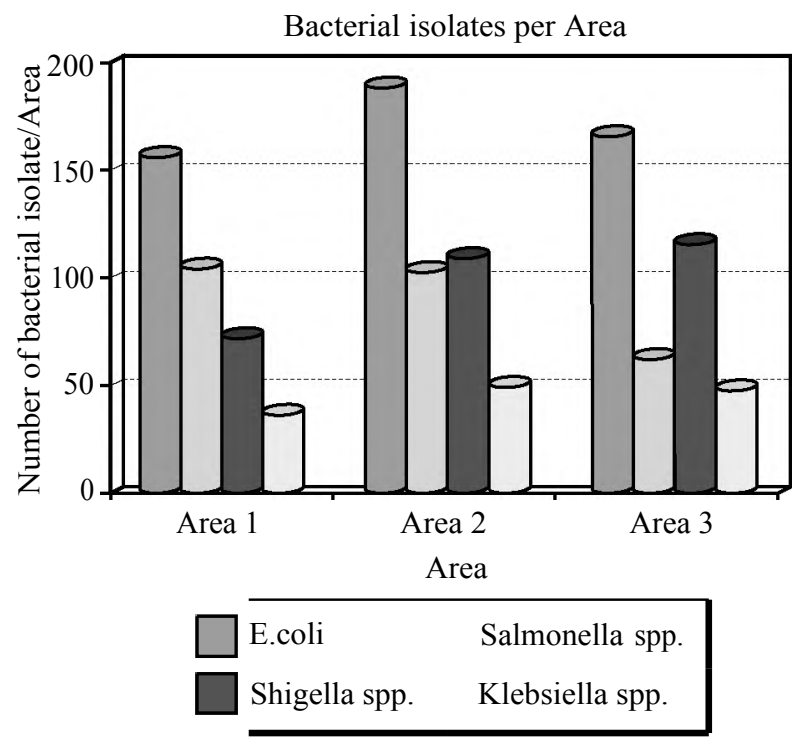

Fig. (4): Bacterial isolates per Area.

\section{Discussion}

Coliform bacteria are present in the environment and feces of all warm-blooded animals and humans. Coliform bacteria are unlikely to cause illness. However, their presence in drinking water indicates that disease-causing organisms (pathogens) could be in the water system. Most pathogens that can contaminate water supplies come from the feces of humans or animals. The total coliform group is a large collection of different kinds of bacteria. Fecal coliforms are types of total coliform that mostly exist in feces. E.coli is a sub-group of fecal coliform. Total coliform, fecal coliform, and E.coli are all indicators of drinking water quality. Coliforms in drinking water may indicate problems with water treatment, the system's treatment is inadequate to deal with source water contamination or is not performing properly, or problems in the distribution system. So public water systems should be monitored for indicators of fecal contamination, and, when coliforms are found, corrective action should be taken as stated by Gruber, Ercumen, Colford [22].

Sadeghi, Mohammadian, Nourani, Peyda, Eslami [23] reported that the quality of drinking water is of great concern to mankind, but drinking water supplies have a long history of being contaminated by a wide spectrum of microbes including the fecal coliforms. Also Akoto, Adiyiah [24] stated that contaminated water can cause a spectrum of diseases ranging from self-limiting gastrointestinal disturbances to severe life threatening infections. World Health Organization (WHO), reported that $80 \%$ of the diseases in developing countries are either water or sanitation related [25]

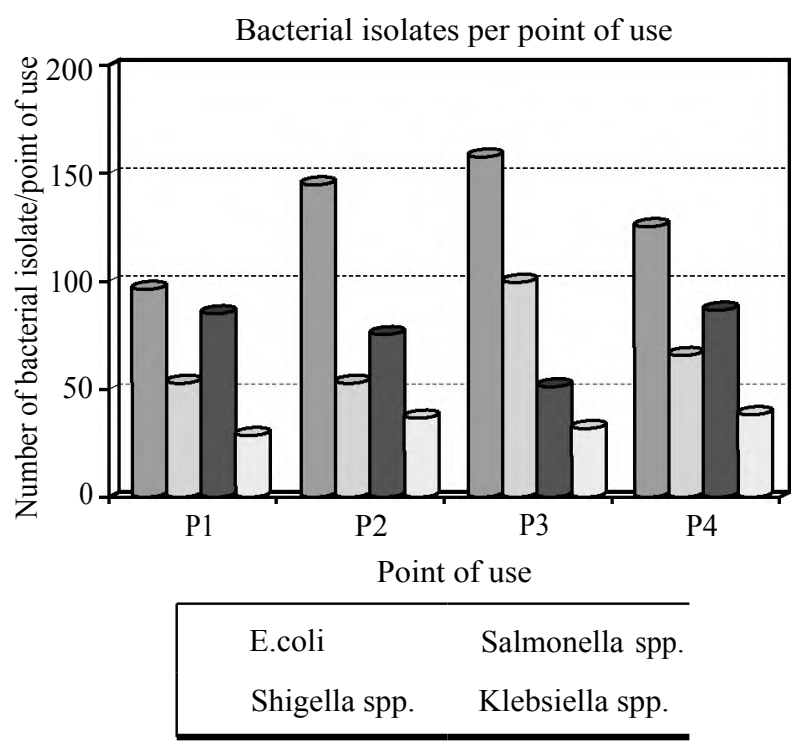

Fig. (5): Bacterial isolates per point of use.

The US centers for disease control recently stated that the number of reported infectious waterborne outbreaks has increased among populations served by small community or private drinking water systems [26]

As regards of the results of bacteriological analysis, all water sampling points were positive for the presence of E.coli, Salmonella spp., Shigella spp., and Klebsiella spp. Our results emphasized that microbial contaminants remained a healthrisk challenge and this comply with Bain, Cronk, Hossain, Bonjour, Onda, Wright et al., [27] who stated that microbial contamination is widespread in lower and middle income countries and affects all water source types, including piped supplies and drinking water is more likely to be contaminated in rural areas than urban areas, and faecal contamination was most prevalent in Africa and South-East Asia. WHO Guidelines for DrinkingWater Quality recommend that Faecal Indicator Bacteria (FIB), preferably E. coli or alternatively Thermo-Tolerant Coliform (TTC), should not be detectable in any $100 \mathrm{ml}$ drinking water sample [28] which is contrast our data that clarify the presence of E.coli in each point of use. Verification of microbial quality of water in supply must be designed to ensure the best possible chance of detecting contamination. Sampling should therefore account for potential variations of water quality in distribution. This will normally mean taking account of locations and of times of increased likelihood of contamination as stated by World Health Organization [29], where our results recorded that summer and autumn months were found to be the highest period of contamination. 


\section{Conclusion:}

Based on the previously discussed results, a high concern about the quality of the drinking water in area of study should be taken.

\section{References}

1- THOMPSON T. and S. KHAN: Situation analysis and epidemiology of infectious disease transmission: A SouthEast Asian regional perspective. Int. J. Environ. Health Res., 13 Suppl 1: p. S29-36, 2003.

2- Global, regional, and national life expectancy, all-cause mortality, and cause-specific mortality for 249 causes of death, 1980-2015: A systematic analysis for the Global Burden of Disease Study 2015. Lancet, 388 (10053): p. 1459-544, 2016.

3- DONIA N.: Survey of potable water quality problems in Egypt, in Eleventh International Water Technology Conference, IWTC112007: Sharm El-Sheikh, Egypt.

4- LAUGHLIN J.: History of water. World of water, 12: p. 7-20, 2000.

5- OLOWE O.A., et al.: Bacteriological quality of water samples in Oshogbo metropolis. Afri. J. Clin. Experiment. Microbiol., 6 (3): p. 219-22, 2015.

6- Le CHEVAILLER M.W., N.J. WEKCHIS and D.B. SMITH: Full-scale studies of factors related to coliform growth in drinking water. Appl. Environ. Microbiol., 62 (7): p. 2201-11, 1996.

7- FLEISHER J.M., et al.: Estimates of the severity of illness associated with bathing in marine recreational waters contaminated with domestic sewage. Int. J. Epidemiol., 27: p. 722-6, 1998

8- ADINGRA A.A., et al.: Bacteriological analysis of surface water collected from the Grand-Lahou lagoon, Cte divoire. Afr. J. Microbiol. Res., 6 (13): p. 3097-105, 2012.

9- FIKSDAL L. and I. TRYLAND: Application of rapid enzyme assay techniques for monitoring of microbial water quality. Curr. Opin. Biotechnol., 19 (3): p. 289-94, 2008.

10- BARTRAM J. and S. PEDLEY: Microbiological analyses, in Water Quality Monitoring-A Practical Guide to the Design and Implementation of Freshwater Quality Studies and Monitoring Programmes, J.B.a.R. Ballance, Editor: United Nations Environment Programme and the World Health Organization (C) 1996 UNEP/WHO, 1996.

11- GILCREAS F.W.: Standard methods for the examination of water and waste water. Am. J. Public Health Nations Health, 56 (3): p. 387-8, 1996.

12- IWRG I.W.R.G.: Sampling and analysis of waters, wastewaters, soils and wastes, in IWRG701, EPA, Editor Regulations: Victoria, 2009.

13- EL-KOWRANY S.I., et al.: Water pollution in the Middle Nile Delta, Egypt: An environmental study. Journal of Advanced Research, 7: p. 781-94, 2016.
14- APHA, A.P.H.A.: Standards methods for the examination of water and wastewater: Washington DC, 1998.

15- BERGEY D.H. and J.G. HOLT: Bergey's manual of determinative bacteriology, 1994.

16-American Public Health Association, A., Standard Methods for the Examination of Water and Wastewater, 21 st ed., American Public Health Association: Washington, D.C, 2005.

17- CORRY J.E.L., G.D.W. CURTIS and R.M. BAIRD: Culture Media for Food Microbiology. Progress in Industrial Microbiology, Elsevier, Amsterdam, 34, 1995.

18- CHOUHAN S.: Recovery of Salmonella and Shigella isolates from drinking water. European Journal of Experimental Biology, 5 (7): 2015.5 (7): p. 49-61, 2015.

19- FELDSINE P., C. ABEYTA and W.H. ANDREWS: AOAC International methods committee guidelines for validation of qualitative and quantitative food microbiological official methods of analysis. J. AOAC. Int., 85 (5): p. 1187-200, 2002.

20- United States Pharmacopeia, U.S.P., The United States pharmacopeia, in United States Pharmacopeia, T.U.S.P. Convention, Editor, United States Pharmacopeial Convention: Rockville, MD. p. Amended Chapters 61, 62, 111,2007

21- HOWARD B.J.: Clinical and Pathogenic Microbiology. 2nd ed: Mosby Year Book, Inc, 1994.

22- GRUBER J.S., A. ERCUMEN and J.M. COLFORD, Jr. Coliform bacteria as indicators of diarrheal risk in household drinking water: Systematic review and meta-analysis. PLoS One, 9 (9): p. e107429, 2014.

23- SADEGHI G.H., et al.: Microbiological quality assessment of rural drinking water supplies in Iran. J. Agri. Soc. Sci., 3: p. 31-3, 2007.

24- AKOTO O. and J. ADIYIAH: Chemical analysis of drinking water from some communities in the Brong Ahafo region. Int. J. Environ. Sci. Tech., 4 (2): p. 211-4, 2007.

25- PRASANNA R.B. and M.S. REDDY: Bacteriological examination of drinking water with reference to coliforms in Jeedimetla, Hyderabad. India. Afr. J. Biotechnol., 8 (20): p. 5495-6, 2009.

26- CRAUN G.F., et al.: Causes of outbreaks associated with drinking water in the United States from 1971 to 2006. Clin. Microbiol. Rev., 23 (3): p. 507-28, 2010.

27- BAIN R., et al.: Global assessment of exposure to faecal contamination through drinking water based on a systematic review. Trop. Med. Int. Health, 19 (8): p. 917-27, 2014.

28- World Health Organization, W., Guidelines for DrinkingWater Quality, WHO: Geneva, 2011

29- World Health Organization, W., Guidelines for drinkingwater quality: Fourth edition incorporating the first addendum, Geneva:World Health Organization, 2017. 


\section{المسح الصحى البكتيرى لمياه الشربفى بعض مناطق محافظة الجيزة اليكري}

مياه الثرب يجب آن تكنف خالية من الروائح الكريهة ومن المواد الكيميائية الضارة والكائنات الدقيقة. من المتوقع آن تتسبب الآمراض مله

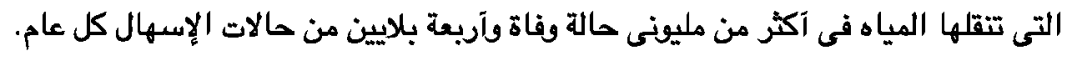

آجريت هذه الدراسة البكتريولوجية على عينات مياه من ثلاث مناطق بمحافظة الجيزة وهى كرداسة وكفر الجبل ودهشور من ديسمبر 17 .

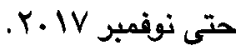

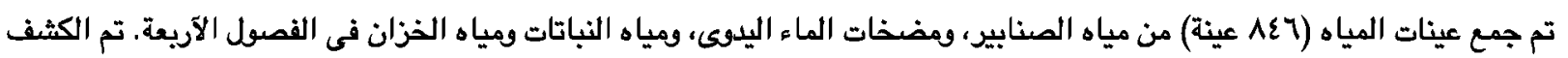

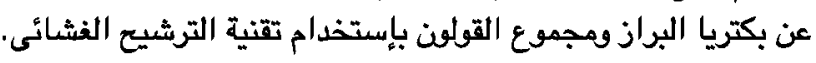

وتمت مقارنة النتائج التى تم الحصلل عليها مع المبادئ التوجيهية لمنظمة الصحة العالمية. من بين مجموع العزلات تم الكثف عن ون

.Klebsiella spp. E.coli, Salmonella spp., Shigella spp.

لذا ينبفى آن يكنن هناك إهتمام آكثر حل نوعية مياة الثرب فى مجال الدراسة. 